\title{
Crude Oil Prices: An Asset Class Analysis on Monetary Policy, Currency Exchange Rate and Nifty 500 with Respect to the Indian Economy
}

\author{
Sunny Oswal ${ }^{1 *}$, Kushagra Goel ${ }^{2}$ \\ ${ }^{1}$ NMIMS University, Mumbai, India \\ ${ }^{2}$ Faculty of Management, NMIMS University, Mumbai, India \\ Email: *sunny.oswal@nmims.edu, kushagra.goel@nmims.edu
}

How to cite this paper: Oswal, S. and Goel, K. (2019) Crude Oil Prices: An Asset Class Analysis on Monetary Policy, Currency Exchange Rate and Nifty 500 with Respect to the Indian Economy. Theoretical Economics Letters, 9, 2678-2698. https://doi.org/10.4236/tel.2019.97168

Received: September 15, 2019

Accepted: October 21, 2019

Published: October 24, 2019

Copyright $\odot 2019$ by author(s) and Scientific Research Publishing Inc. This work is licensed under the Creative Commons Attribution International License (CC BY 4.0).

http://creativecommons.org/licenses/by/4.0/

\begin{abstract}
Crude oil is an essential commodity for an economy, hence its requirement has seen a rapid growth in India. To subdue inflation, and a sustainable and rapid economic growth, crude oil plays a crucial role. India has been positioned as the $4^{\text {th }}$ largest consumer of crude oil by importing 100 million tons of crude oil every year, which accounts for almost 37 percent of the total import. Crude is a price determinant among various other commodities as a rise or fall in its prices has a direct impact on prices of various commodities and society. An increase in oil price leads to an appreciation in the exchange rate in oil exporting countries and depreciation in oil importing countries. Reduction of one dollar leads to a three-fold effect in the economy and saves about 40 billion rupees. This study analyses the impact of crude oil prices on the Indian economy. In order to analyse the impact, the study uses variables like stock index, monetary policies and currency exchange rates, and we have employed statistical techniques such as Augmented Dickey Fuller, correlation, co-integration and regression. The study finally concludes that crude oil prices have a significant impact on exchange rate, inflation and interest rates.
\end{abstract}

\section{Keywords}

Inflation, Interest Rate, Currency Exchange Rate, Nifty 500, Gross Domestic Product

\section{Context and Introduction}

\subsection{Crude Oil}

The history of crude oil is marked by economic and political incidents, changes in the petroleum industry, and advancement in technology, which still affects the 
prices today. When we talk about crude oil prices, OPEC inevitably comes up. OPEC was formed in 1960 in Baghdad with the support from Kuwait, Iran, Iraq, Saudi Arabia and Venezuela. Over the years, this cartel has amplified to include Qatar, Indonesia, Libya, United Arab, Gabon, Nigeria and Ecuador.

Invention of Iraq by the US in 2003 leads to an uncertainty about the future of supply of oil. During the same time period, Asian demand for oil (mainly driven by China) had massively increased to result in an increase in the oil prices from $\$ 28.38$ in July 2000 to over $\$ 146.02$ in July 2008. Prices fell and rebounded during the financial crisis in 2008, decreasing to \$126.48 followed by Arab spring of 2011, creating supply shortage.

Recent technological advancements, such as introduction of hydraulic fracturing, have facilitated the increase in US shale oil production. This reduced OPEC's influence on prices and caused a fall in prices from \$114.84 per barrel in June 2014 to as low as \$28.47 in January 2016.

India has the second largest population in the world with the population of about 132.42 (World Bank, 2016). A large population will have a higher demand for crude oil, precisely 213.93 million tonnes (oil ministry's petroleum planning and analysis cell, 2016-2017) in the fiscal year 2016-2017 and had pegged imports at 219.15 (oil ministry's petroleum planning and analysis cell, 2017-2018) for year 2017-2018. Reason for such an increase can be attributed to the upcoming and advancing agricultural and non-agricultural sectors, including the advancement in the automobile sector. India now relies on more than $80 \%$ oil that is imported to meet its oil demand. So, needless to say, crude oil prices affect the nation to a certain extend which we prove in this research paper.

Going ahead, the inflation standpoint is required to be impacted by a few variables. To start with, sustenance inflation has remained uncommonly kind, which gives a descending inclination to its direction in the second $50 \%$ of the year. Inflation in key sustenance things, for example, beats, consumable oils, sugar, foods grown from the ground remains extraordinarily delicate at this crossroads. The hazard to nourishment inflation from spatially and transiently uneven precipitation is likewise moderated, as affirmed by the primary development appraises that have put the creation of major Kharif crops for 2018-2019 higher than the record a year ago. A gauge of the effect of an expansion in minimum support prices (MSPs) declared in July has been figured in the standard projections.

Also, the cost of the Indian demand for crude oil has expanded pointedly, by US\$ 13 a barrel, since the last resolution. Thirdly, global financial markets stayed unstable with EME monetary standards deteriorating altogether. At last, the HRA impact fell off its crest in June and is dispersing step by step on expected lines. Mulling over every one of these variables, inflation is anticipated at 4.0 for each penny in Q2: 2018-2019, 3.9 - 4.5 for every penny in H2 and 4.8 for each penny in Q1: 2019-2020, with dangers to some degree to the upside. Barring the HRA affect, CPI inflation is anticipated at 3.7 for each penny in Q2: 2018-2019, 
3.8 - 4.5 for each penny in H2 and 4.8 for each penny in Q1: 2019-2020.

Annual consumer inflation in India has decreased to $3.96 \%$ from $4.17 \%$ (July) in August 2018, which was below the market expectation of 3.86\%. This is the lowest inflation rate since October of 2017, the main cause being the slowdown in food cost.

\subsection{Rupee Exchange Rate}

The value of a free currency like Rupee depends on its demand in the currency market. Therefore, it largely depends on the current account deficit. A high current account deficit implies that the country must sell rupees and buy dollars to pay its bills. This, in turn, results in depreciation in the value of the rupee.

In 2008, RBI kept buying the incoming dollars to manage rupee, and to sterilize the country from inflation by the rupees it had to print to buy those dollars, there were "sterilization bonds" issued.

In 2011 and 2013, the inflation in India had seen new heights. The inflation levels had risen to a near double-digit inflation and the rupee against a dollar crossed 50 for the first time. In 2013, there was a rumour that went about saying that the loose monetary policies of the west were going to be unwounded. This resulted in the investors taking the money out of the emerging market which subsequently leads to rupee hitting a new low at Rs. 68 a dollar in July and August 2013.

Recently, the rupee depreciated to Rs. 72 per dollar. This can be attributed to the emerging markets sliding against the dollar. The ruble and the Brazilian lira are down by $20 \%$ and $25 \%$ respectively. India, even though, is down by $11 \%$, it is the highest seen as an annual change since 2013 (Figure 1).

A negative skew of 0.085 (Figure 1) suggests that the data is skewed towards the left which implies that exchange rates decrease significantly sometimes, which may be because of trade and change in the amount of reserves held by a nation, among other factors, which leads to a reduced mean. A negative Kurtosis of 1.48 indicates that the curve is platykurtic, which means that it has lighter tails and a flatter peak than a normal distribution. A normal test stat of 0.91 suggests that the data is normal and a $P$-value of 0 implies that the data is significant.

\subsection{Interest Rates}

While views are mixed, the reality is that oil prices and interest rates have some correlation between their movements but are not correlated exclusively (Figure 2).

A positive skew (Figure 2) of 0.66 suggests that the data is skewed towards the right which implies that interest rate is raised sometimes and because of those few years, the mean rises. A negative Kurtosis of 0.09 indicates that the curve is leptokurtic, which means that it has heavier tails and a sharper peak than a normal distribution. A normal test stat of 0.92 suggests that the data is normal and a $P$-value of 0.39 implies that the data is not significant. 
USD to INR Retes over the years
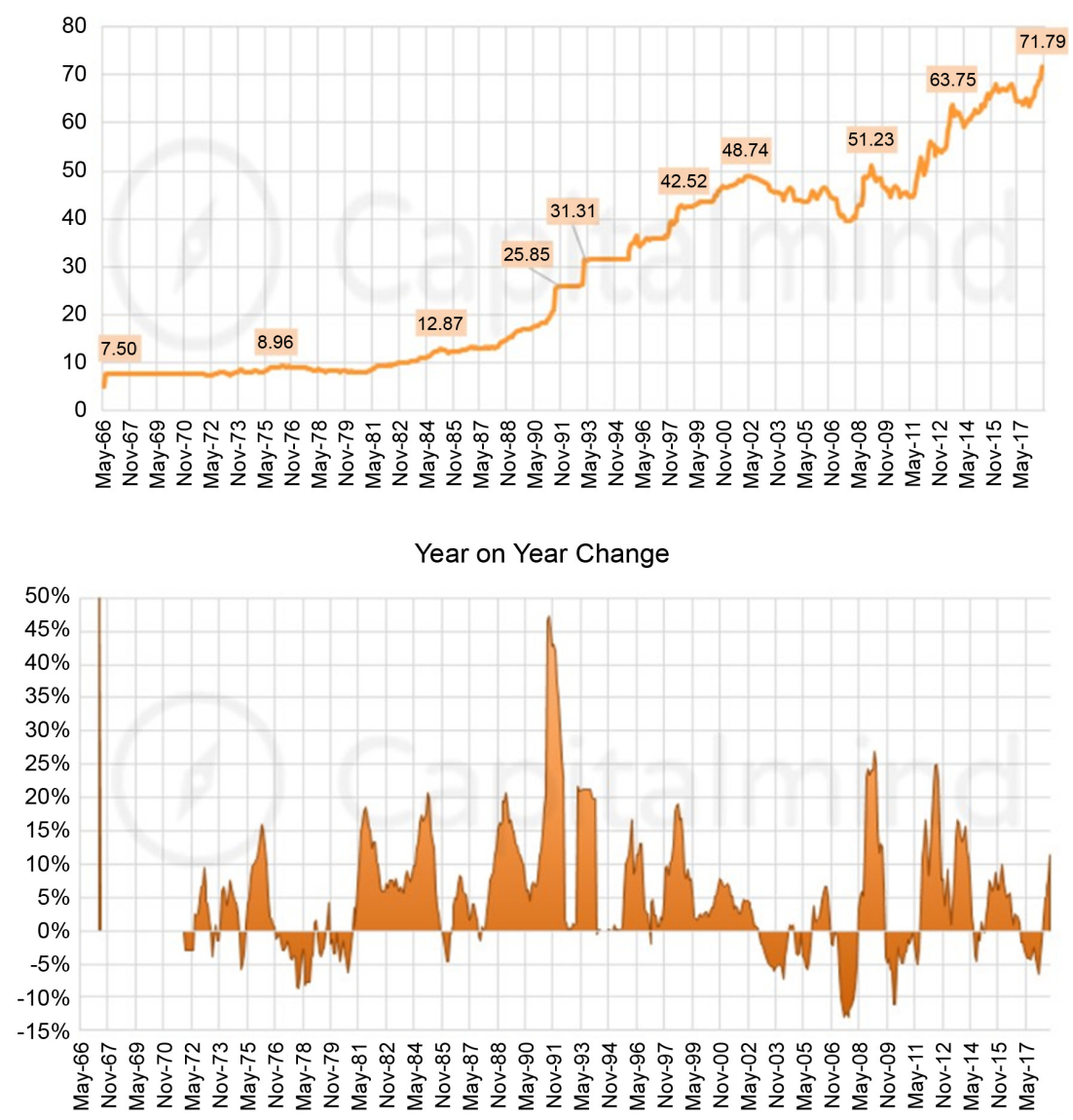

Figure 1. USD to INR rates (Source: Capitalmind).

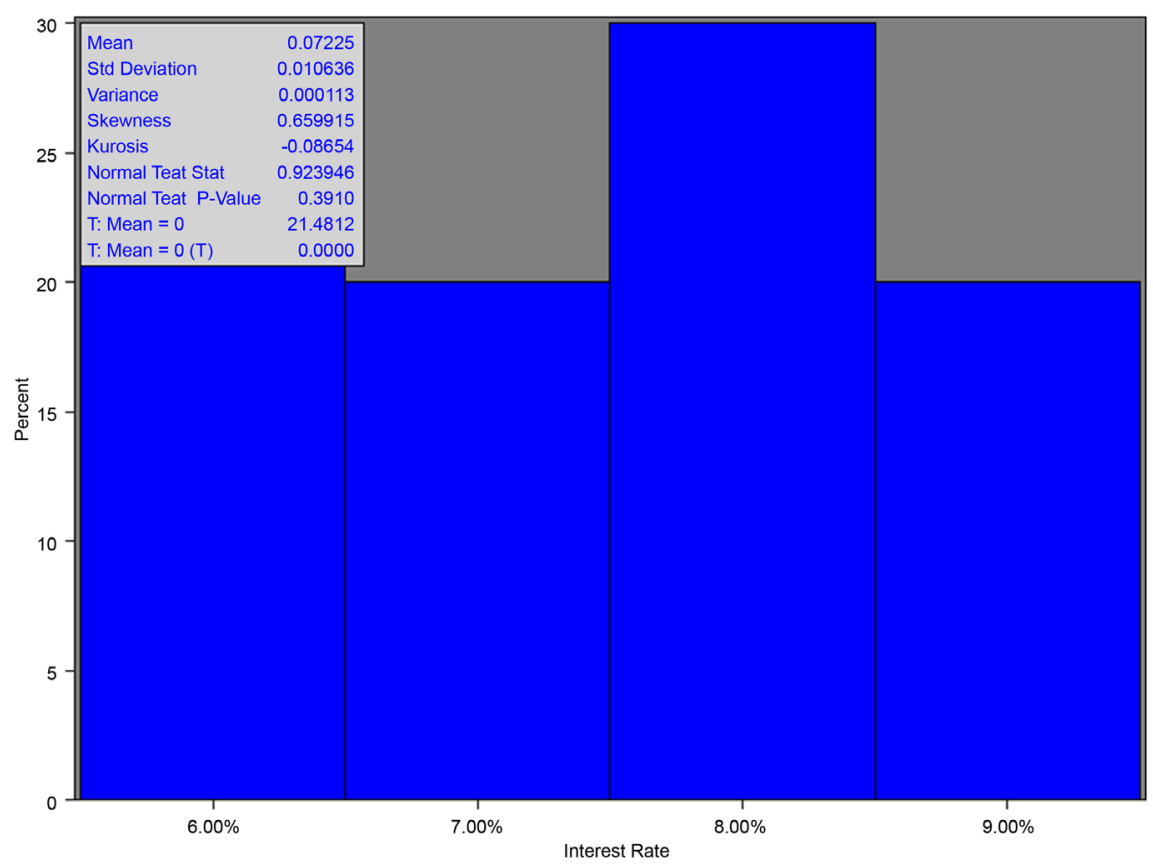

Figure 2. Percentage correlation between oil prices and interest rates (Source: Author generated). 


\subsection{Nifty 500}

NIFTY 500 is a flagship index of NSE (HQ-Mumbai) which represents about $95.2 \%$ of free float market capitalization of the stocks listed on NSE as on $31^{\text {st }}$ March 2017. The aggregate traded value throughout the previous a half year finishing March 2017, of all Index constituents, is roughly 91.7\% of the traded estimation of all stocks on NSE (Figure 3).

A positive skew (Figure 3 ) of 0.49 suggests that the data is skewed towards the right which implies that Nifty shoots up as the stock market are volatile sometimes and because of those few months, the mean is inflated. A negative Kurtosis of 0.46 indicates that the curve is platykurtic, which means that it has lighter tails and a flatter peak than a normal distribution. A normal test stat of 0.94 suggests that the data is normal and a $P$-value of 0 implies that the data is significant.

\subsection{Benchmark Crude}

In the late 1980s, new benchmark rough evaluations developed. A benchmark rough review fills in as the reference for unrefined of comparable characteristics and areas. Middle Eastern Light, with its $5 \mathrm{MBD}$ generation volume, was the benchmark unrefined under OPEC's official offering value framework [1]. In any case, in light of the improvement of spot and fates markets, the job of Arabian Light was assumed control by West Texas Intermediate (WTI) and Brent.

North Sea Brent has the majority of the indispensable criteria for a seat marker: security of supply, assorted variety of dealers and wide acknowledgment by refineries and consumers. In spite of the fact that Brent was not the biggest field in the North Sea and had confronted creation issues before, its satellite fields gave enough generation volumes to market exchanging liquidity. A critical factor

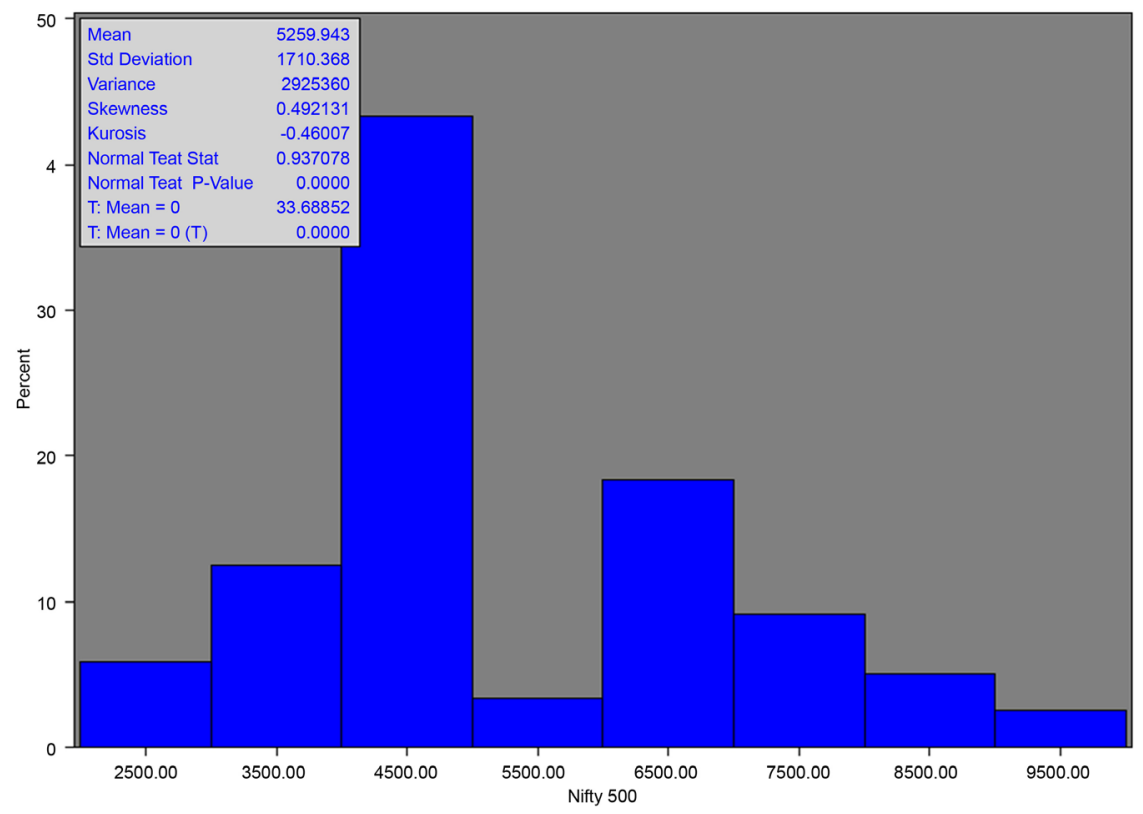

Figure 3. Percentage correlation between market cap and Nifty 500 (Source: Author generated). 
is that creation is shared by a few members and isn't amassed in a solitary maker. This was the fundamental motivation behind why Forties, whose generation was commanded by BP, did not turn into the North Sea benchmark, in spite of it being the main real North Sea oil field to come on stream, and that its creation was bigger than that of Brent.

WTI was chosen as the reference review for raw petroleum prospects contract at the New York Mercantile Exchange (NYMEX) in 1983. Its landlocked conveyance framework and the separation from global markets may not best suit the conditions for a benchmark review. Nor does it have an extensive physical generation. In any case, exchanging at the NYMEX saw an immense achievement. With substantial exchanging volumes, overall WTI has increased.

While the money related market arranged WTI responds instantly to market recognitions, Brent's linkage to the physical markets gives a photo of the global supply request relationship. Benchmark grades are basic in characterizing the costs of other related unrefined. They turned into the key value factors in many evaluating equations. What's more, since the two benchmarks are the reference for exchange the prospects markets, they additionally turned into the reason for most supporting and hazard administration activities and pulled in all the more exchanging premiums in the markets.

While the benchmarks assume the key job in characterizing the supreme value levels, most other unrefined are exchanged the type of spread exchanging. The inclination for spread exchanging mirrors a characteristic response to the unpredictability that is normal in worldwide oil markets. The contrasts between costs tend to be less unstable than supreme value tend to be less unpredictable than total value levels. Spread exchanging mirrors a requirement for markets to continually alter market connections in value vacillations [2]. There is also a significant correlation between inflation and crude oil [3].

\section{Theoretical Underpinnings and Extant Review of Literature}

Global economic activities have been a major factor that affects the prices of the crude oil. In the research paper, "Global economic activity and crude oil prices: A co-integration analysis" (Energy Economics, 2010), the authors, Yanan He, Shouyang Wang and Kin Keung Lai, investigate the relationship between crude and global economic activity [4]. The study uses Killian economic index as a global economic activity indicator and later the error correction model (sensible economic properties). The study concludes that the crude oil prices are influenced significantly by fluctuations in the Kilian economic index through both long-run equilibrium conditions and short-run impacts. In this paper, we aim to investigate the relationship between the economic activity and the crude oil prices, and the significance of change.

Crude oil price plays an important role in determining the price of goods and commodities and hence the inflation, it plays a vital role in giving a final touch 
to the monetary policy. In the research paper "Impact of Oil Prices on the Indian Economy" by the author A. Aparna, the purpose of the study is Crude oil prices play a very significant role in the economy of any country [5]. India's growth story hovers around the import of oil as India imports $70 \%$ of its crude requirements. In this paper, the author has attempted to study crude oil prices on Indian Economy taking into consideration GDP and WPI as relevant variables. Since direct causal relationship could not be established, Vector Auto Regression is used to analyse the objective. Oil impacts the economy through various channels. This study restricts itself to analysing the direct impact of oil prices on the WPI and IIP, and thereby on the GDP of the country.

The research paper by the C.S. Shahid establishes the influence of crude oil price on the monetary policy by validating a relationship between crude oil price and Inflation over a period of 14 years. In this paper, Karl Pearson's Coefficient of Correlation (Covariance method) has been employed to determine the variation in inflation because of variation in crude oil price. The paper concludes that the crude oil prices across the globe have a significant impact on global economies directly or indirectly and any positive change in the crude oil price has negative impact on the increment in GDP of a country [6].

In the research paper "Impact of Increase in Oil Prices on Inflation and Output in India" (published in Economic and political weekly, in January 2001), Kaushik Bhatacharya and Indranil Bhattacharya attempted to study the transmission mechanism of an increase in crude oil prices on the prices of other commodities and output in India [7]. Using a four equation VAR model on oil and non-oil inflation, and growth in broad money and output, it attempted to identify the lag structure in which a rise in the prices of mineral oil begins to affect the prices of other commodities and output, consequently affecting the inflation in our country which is then used to shape the monetary policy. It is expected that such analyses which are beyond the scope of the current paper would provide valuable insights on the transmission of demand and supply shocks on inflation and output in the Indian economy.

Changes in prices of oil directly affect the exchange rate of the countries i.e. an increase in oil price leads to an appreciation in the exchange rate in oil exporting countries and depreciation in oil importing countries. The research paper, "Examining crude oil price-Exchange rate nexus for India during the period of extreme oil price volatility" published by Sajal Ghosh in "Applied Economics" in 2011, probes crude oil price-exchange rate nexus for India using daily data for the time span of July 2, 2007-November 28, 2008. Generalized Auto-Regressive Conditional Heteroscedasticity (GARCH) and exponential GARCH (EGARCH) models have been employed to examine the impact of oil price shocks on nominal exchange rate [8]. The study concludes that Indian currency depreciates vis-à-vis US dollar when the oil price return increases; positive and negative oil price shocks have similar effects, in terms of magnitude, on exchange rate volatility; and the oil price shocks have permanent effect on exchange rate volatility. 
In the research paper, "The impact of oil shocks on exchange rates: A Markov-switching approach" by the author Syed Abul, Basher, Alfred, A. Haug and Perry Sadorsky (published in the journal, "Energy Economics" February 2016), Markov-switching models are used to investigate the impact of oil shocks on real exchange rates for a sample of oil exporting and oil importing countries [9].

In the research Topic "Oil price shocks and stock market activity" by author Perry Sadorski (published in "Energy Economics" 1 in October 1999), the purpose of study is that the result obtained from a vector auto regression show that oil prices and oil price volatility both play important roles in affecting real stock returns [10].

In the research paper, "The impact of oil price shocks on the stock market return and volatility relationship" by the author Wensheng Kang, Ronald A. Ratti and Kyung Hwan Yoon (published in "Journal of International Financial Markets, Institutions and Money" in January 2015), the purpose of study is that this paper examines the impact of structural oil price shocks on the covariance of U.S. stock market return and stock market volatility [11].

The crude oil prices seem to have a considerable impact on the stock index. The research paper, "Does oil move equity prices? A global view", published by "Mohan Nandha" and "Robert Faff" in "Energy Economics" in 2008, proposes to study whether and to what extent the adverse effects of oil price shocks impact the stock market returns [12]. To reach a conclusion, 35 global industry indices for the period from April 1983 to September 2008 were analyzed. The findings indicate that the rise in crude oil prices has a negative impact on the equity returns for all sectors except a few (namely-mining, oil and gas industries). It also states the existence of a little asymmetry in the oil price sensitivities. Increases in oil prices have been held responsible for recessions, periods of excessive inflation, reduced productivity and lower economic growth [13].

\section{Research Approach}

The study is recursive in nature. The data for the study between 2008 and 2018 has been retrieved from reliable secondary sources. The statistical tools such as regression and inter-correlation have been used to infer the data.

\subsection{Hypothesis}

$\mathrm{H}_{0}$ - Changes in crude oil prices impact inflation.

$\mathrm{H}_{1}$-Changes in crude oil prices do not impact inflation.

$\mathrm{H}_{0}$ - Changes in crude oil prices impact the currency exchange rate.

$\mathrm{H}_{1}$-Changes in crude oil prices do not impact the currency exchange rate.

$\mathrm{H}_{0}$ - Changes in crude oil prices impact the stock index.

$\mathrm{H}_{1}$-Changes in crude oil prices do not impact the stock index.

$\mathrm{H}_{0}$-Changes in crude oil prices impact interest rate.

$\mathrm{H}_{1}$ - Changes in crude oil prices do not impact interest rate.

$\mathrm{H}_{0}$-Crude oil prices and Nifty 500 returns are stationary.

$\mathrm{H}_{1}$-Crude oil prices and Nifty 500 returns are not stationary. 
$\mathrm{H}_{0}$-Crude oil prices and Nifty 500 are co-integrated.

$\mathrm{H}_{1}$-Crude oil prices and Nifty 500 are not co-integrated.

$\mathrm{H}_{0}$-Changes in Interest rate affect Nifty 500 returns.

$\mathrm{H}_{1}$-Changes in interest rate does not affect Nifty 500 returns.

$\mathrm{H}_{0}$-Changes in exchange rate affects Nifty 500 returns.

$\mathrm{H}_{1}$-Changes in exchange rate does not affect Nifty 500 returns.

$\mathrm{H}_{0}$-Changes in CPI affect Nifty 500 returns.

$\mathrm{H}_{1}$-Changes in CPI does not affect Nifty 500 returns.

\subsection{Sample Size and Justification}

The fundamental purpose of this study is to examine whether crude oil price affects inflation, interest rate, and currency exchange rate and what is the extent of impact. Our study period is from calendar year 2008-2017. The data has been collected on monthly basis. This period is important because so many events have taken place around the world including the price of crude oil being $\$ 147.27$ per barrel (11 $1^{\text {th }}$ Aug. 2008).

Quarterly data were also collected for crude oil price change of India basket, inflation and GDP growth base year (2004-2005) of new series from 2005-2006 to 2009-2010 for carrying out the study with sample size 20 .

\section{Analysis and Discussion}

\subsection{Econometrics Modelling for the Hypothesis Model}

\subsubsection{Model 1: Regression}

The two basic types of regression are linear regression and multiple linear regression, although there are non-linear regression methods for more complicated data and analysis. Linear regression uses one independent variable to explain or predict the outcome of the dependent variable $\mathrm{Y}$, while multiple regression uses two or more independent variables to predict the outcome.

Linear Regression:

$$
Y=a+b X+u
$$

Multiple Regression:

$$
Y=a+b_{1} X_{1}+b_{2} X_{2}+b_{3} X_{3}+\cdots+b_{t} X_{t}+u
$$

where:

$Y=$ the variable that you are trying to predict (dependent variable).

$X=$ the variable that you are using to predict $Y$ (independent variable).

$a=$ the intercept.

$b=$ the slope.

$u=$ the regression residual.

Regression takes a group of random variables, thought to be predicting $Y$, and tries to find a mathematical relationship between them. This relationship is typically in the form of a straight line (linear regression) that best approximates all the individual data points. In multiple regression, the separate variables are differentiated by using numbers with subscript. 


\subsubsection{Model 2: Augmented Dickey Fuller}

The Augmented Dickey Fuller Test (ADF) is unit root test for stationarity. Unit roots can cause unpredictable results in your time series analysis.

The Augmented Dickey-Fuller test can be used with serial correlation. The ADF test can handle more complex models than the Dickey-Fuller test, and it is also more powerful. That said, it should be used with caution because-like most unit root tests-it has a relatively high Type I error rate.

$$
\Delta Y_{t}=\mu+\beta Y_{t-1}-\sum_{j=1}^{p} \alpha_{j} \Delta Y_{t-j}+\varepsilon_{t}
$$

Although software will run the test, it's usually up to you to interpret the results. In general, a $P$-value of less than $5 \%$ means you can reject the null hypothesis that there is a unit root. You can also compare the calculated $\mathrm{DF}_{\mathrm{T}}$ statistic with a tabulated critical value. If the $\mathrm{DF}_{\mathrm{T}}$ statistic is more negative than the table value, reject the null hypothesis of a unit root.

\subsubsection{Model 3: Johansen Co-Integration Test}

Co-integration tests analyse non-stationary time series processes that have variances and means that vary over time. In other words, the method allows you to estimate the long-run parameters or equilibrium in systems with unit root variables [14].

Two sets of variables are co-integrated if a linear combination of those variables has a lower order of integration. Oil price shocks affect the output growth of selected MENA countries that are considered either net exporters or net importers of this commodity, but are too small to affect oil prices [15].

\subsubsection{Model 4: GARCH Model}

The generalized autoregressive conditional heteroscedasticity (GARCH) process is an econometric term developed in 1982 by Robert F. Engle to describe an approach to estimate volatility in financial markets. There are several forms of GARCH modelling. The GARCH process is often preferred by financial modelling professionals as it provides a more real-world context than other forms when trying to predict the prices and rates of financial instruments [16].

\subsection{Relationship between Crude Oil and Inflation and Nifty}

\subsubsection{Impact of Crude Oil on Inflation}

One of the main impacts from oil prices changes is inflation/changes on price. Fluctuations in inflation or price further lead to economic changes which affect the performance of the economy as well. Due to this, the inflation rate is the main indicator of the state or the growth of the economy even in countries like France [17].

The macroeconomic performance of a set of industrialized economies in the aftermath of the oil price shocks of the 1970s is not very encouraging [18].

Oil constitutes $6 \%$ of the CPI and $2.4 \%$ in headline inflation. Therefore, any changes in the price will affect the inflation. The notion is that we tend to equate 
inflation as a negative trigger for equity market. Higher inflation means higher cost of living and lower purchasing power. When inflation goes up, people earn less in real terms and thus results in lower returns net of inflation. Nifty 500 includes $8.6 \%$ of FMCG companies thus inflation will affect those FMCG companies and thus Nifty.

\subsubsection{Impact of Inflation on Nifty}

Stocks are often categorized into value and growth. Value stocks have strong current cash flows that will slow over time, while growth stocks have little or no cash flow today, but it will gradually increase over time.

The results obtained in Table 1 indicate that there is a positive, however, a statistically insignificant correlation between Crude oil and CPI.

The results also indicate that there is a positive as well as statistically significant correlation between Nifty 500 return and Crude oil return. Hence, it can be stated that if the Crude oil price rises, the Sensex return will also rise and if Crude Oil price falls the Sensex price also falls. The result finally reveals that there is a negative and statistically insignificant correlation between Nifty return and CPI. This indicates that if the value of CPI falls, the Nifty return will increase and vice-versa.

It can be concluded (Table 2 ) that $1 \%$ change in crude oil prices will lead to an increase in the Inflation by $0.06 \%$. The $\mathrm{R}$-squared value is $33.97 \%$. So, the variation in model due to change in crude oil price is explained by $33.97 \%$ and rest of the variation is explained by other factors. Crude oil price affects Inflation by $33.97 \%$. However, it has been proved statistically insignificant by having a $P$-value of 0.077 which is greater than 0.05 .

It can be concluded (Table 3 ) that a $1 \%$ change in Inflation rate does not have

Table 1. Correlation matrix between CPI, crude oil and nifty.

\begin{tabular}{cccc}
\hline & Crude oil & CPI & Nifty 500 \\
\hline Crude oil & 1 & 0.5827 & 0.0712 \\
CPI & 0.5827 & 1 & -0.7545 \\
Nifty 500 & 0.0712 & -0.7545 & 1 \\
\hline
\end{tabular}

(Source: Author generated).

Table 2. Regression of crude oil on inflation.

\begin{tabular}{cccccc}
\hline Variable & Coefficient & Standard Error & t-Statistic & $\boldsymbol{R}$ Square & Probability \\
\hline Inflation & 0.0006 & 0.0003 & 2.0285 & 0.3397 & 0.0770 \\
\hline
\end{tabular}

(Source: Author generated).

Table 3. Regression of inflation on Nifty 500.

\begin{tabular}{cccccc}
\hline Variable & Coefficient & Standard Error & t-Statistic & $\boldsymbol{R}$ Square & Probability \\
\hline Nifty 500 & 0.0000 & 0.0000 & -3.2517 & 0.5693 & 0.0117 \\
\hline
\end{tabular}

(Source: Author generated). 
a significant impact on Nifty 500 . The R squared value is $56.93 \%$. So, the variation in model due to change in the Interest rate is explained by $56.93 \%$ and rest of the variation is explained by other factors. Interest rates affect Nifty by $56.93 \%$. Also, it has been proved statistically significant by having a $P$-value of 0.0117 which is less than 0.05 .

\subsubsection{Relationship between Crude Oil and Exchange Rate and Nifty: Crude Oil Impact on Exchange Rate}

A large Indian population will have a demand for crude oil mainly because of the advancement of agricultural and non-agricultural sectors, including advancements in the automobile sectors. Oil prices are denominated in US dollars hence there is going to be a significant impact on the demand as well as the supply of the foreign exchange. Oil prices are denominated in US dollars hence there is going to be a significant impact on the demand as well as the supply of the foreign exchange. There are many papers which investigate the relationship between oil prices and exchange rate. Ghosh (2011) used daily data 2007-2008 revealed that an increase in the oil price leads to the depreciation of Indian currency and vis-á-vis the U.S. dollar. He also inferred a permanent effect on the exchange rate volatility. Ghosh was able to prove that shocks to exchange rate have a symmetric effect oil price shocks have similar magnitude effects on the exchange rate. When there is an increase or an expected increase in the process of oil, the Indian refineries are obligated to acquire more dollars to pay for the rise in the imports leading to depreciation of Indian currency.

India shifted from using a fixed exchange rate policy to a flexible exchange rate policy in 1993, which also makes the oil price changes, an important factor affecting the currency value. We attempt to find the correlation between the crude oil prices and exchange rate. There is a positive correlation of 0.0313 between crude oil prices and exchange rate which signifies that when the oil prices rise, Indian rupee depreciates in relation to US dollar. Since India is an importer of oil, when oil prices go up, India shells out more INR in terms of dollars which leads to an appreciation of USD.

\subsection{Exchange Rate Impact on Nifty}

The results obtained in Table 4 indicate that there is a positive, however, a statistically insignificant correlation between Crude oil and Exchange rate.

The results also indicate that there is a positive as well as statistically significant correlation between Nifty 500 return and Crude oil return. Hence, it can be stated that if the Crude oil price rises, the Sensex return will also rise and if Crude Oil price falls the Sensex price also falls. The result finally reveals that there is a negative as well as statistically significant correlation between Sensex return and Rupee-Dollar exchange rates. This indicates that if Rupee value depreciates the Sensex return will fall and if the Rupee value appreciates the Sensex return will rise.

From the above Table 5, it can be concluded that $1 \%$ change in crude oil 
Table 4. Correlation matrix between crude oil, exchange rate and Nifty 500 .

\begin{tabular}{cccc}
\hline & Crude Oil & Exchange Rate & Nifty500 \\
\hline Crude Oil & 1 & 0.03129 & 0.07121 \\
Exchange Rate & 0.03129 & 1 & -0.64784 \\
Nifty500 & 0.07121 & -0.64784 & 1 \\
\hline
\end{tabular}

(Source: Author generated).

Table 5. Regression of crude oil on exchange.

\begin{tabular}{cccccc}
\hline Variable & Coefficient & Standard Error & t-Statistic & $\boldsymbol{R}$ Square & Prob \\
\hline Exchange rate & 0.0076 & 0.0225 & 0.3386 & 0.00098 & 0.7356 \\
\hline
\end{tabular}

(Source: Author generated).

prices will lead to an increase in the Exchange rate by $0.76 \%$. The R-squared value is $0.098 \%$. So, the variation in model due to change in crude oil price is explained by $0.098 \%$ and rest of the variation is explained by other factors. Crude oil price affects exchange rates by $0.098 \%$. However, it has been proved statistically insignificant by having a $P$-value of 0.7356 which is greater than 0.05 .

It can be concluded (Table 6) that a $1 \%$ change in Exchange rate leads to a downside in Nifty 500 by $175 \%$. The R squared value is $41.97 \%$. So, the variation in model due to change in the exchange rate is explained by $41.97 \%$ and rest of the variation is explained by other factors. Crude oil price affects exchange rates by $41.97 \%$. Also, it has been proved statistically significant by having a $P$-value of less than 0.05 .

\subsection{Relationship between Crude Oil and Interest Rates and Nifty: Impact of Crude Oil on Interest Rates}

The impact of crude oil prices on interest rate is indirect [19]. The interest rate is determined by considering the level of inflation that prevails [20]. Hence, the fluctuations in crude oil prices that affect the inflation in turns affect the interest rate. There is an indirect relationship between Crude oil and interest rates. The past two decades have seen a series of price and quantity shocks in oil markets which have had important consequences for most of the world's economies [21].

\subsection{Impact of Interest Rates on Nifty}

The MPC decides the interest rate which is based on Inflation and hence there is an indirect relationship between inflation and interest rate. Mainly the interest rate is changed to maintain the inflation in the country. OPEC pricing and output strategies too has an effect on the same [22].

The results obtained in Table 7 indicate that there is a positive, however, a statistically insignificant correlation between Crude oil and Interest rate.

The results also indicate that there is a positive as well as statistically insignificant correlation between Nifty 500 return and Crude oil return. Hence, it can 
Table 6. Regression of exchange rate on Nifty 500.

\begin{tabular}{cccccc}
\hline Variable & Coefficient & Standard Error & t-Statistic & $\boldsymbol{R}$ Square & Probability \\
\hline Nifty 500 & -1.7524 & 0.1905 & -9.1988 & 0.4197 & 0.0000 \\
\hline
\end{tabular}

(Source: Author generated).

Table 7. Correlation matrix between crude oil, interest rate and Nifty 500.

\begin{tabular}{rccc}
\hline & Crude Oil & Interest Rate & Nifty500 \\
\hline Crude Oil & 1 & 0.0494 & 0.0712 \\
Interest Rate & 0.0494 & 1 & 0.1451 \\
Nifty500 & 0.0712 & 0.1451 & 1 \\
\hline
\end{tabular}

(Source: Author generated).

be stated that if the Crude oil price rises the Sensex return will also rise and if Crude Oil price falls the Sensex price also falls. The result finally reveals that there is a positive and statistically insignificant correlation between Nifty return and Interest rates. This indicates that if the crude oil price falls, the Nifty return will increase and vice-versa.

It can be concluded (Table 8 ) that $1 \%$ change in crude oil prices does not increase the interest rate by a large extent. The R-squared value is $0.24 \%$. So, the variation in model due to change in crude oil price is explained by $0.24 \%$ and rest of the variation is explained by other factors. Crude oil price affects exchange rates by $0.24 \%$. However, it has been proved statistically insignificant by having a $P$-value of 0.8920 which is greater than 0.05 .

It can be concluded (Table 9 ) that a $1 \%$ change in interest rate has quite an impact on Nifty. The R squared value is $2.1 \%$. So, the variation in model due to change in the exchange rate is explained by $2.1 \%$ and rest of the variation is explained by other factors. Also, it has been proved statistically insignificant by having a $P$-value of more than 0.05 .

It can be concluded (Table 10) that $1 \%$ change in crude oil prices will lead to an increase in the Nifty 500 by $4.7 \%$. The R-squared value is $0.51 \%$. So, the variation in model due to change in crude oil price is explained by $0.51 \%$ and rest of the variation is explained by other factors. Crude oil price affects Inflation by $0.51 \%$. However, it has been proved statistically insignificant by having a $P$-value of 0.4415 which is greater than 0.05 .

\subsection{Relationship between Oil and Aviation Companies and Crude Oil, Exchange Rate and Nifty}

From Table 11, we can infer that the correlation between stock return of National Thermal Power Corporation Limited, Powergrid Corporation, Hindustan Petroleum Corporation limited and Indraprastha Gas Limited with Crude oil return is negative and statistically significant. This implies that if there is an increase in Crude Oil price then the Stock price of the companies will decrease 
Table 8. Regression of crude oil on interest rates.

\begin{tabular}{cccccc}
\hline Variable & Coefficient & Standard Error & t-Statistic & $R$ Square & Probability \\
\hline Interest rate & 0.0000 & 0.0000 & 0.1402 & 0.0024 & 0.8920 \\
\hline
\end{tabular}

(Source: Author generated).

Table 9. Regression of Interest rates on Nifty 500.

\begin{tabular}{cccccc}
\hline Variable & Coefficient & Standard Error & t-Statistic & $\boldsymbol{R}$ Square & Probability \\
\hline Nifty500 & 27926.14 & 67337.33 & 0.4147 & 0.0210 & 0.6892 \\
\hline
\end{tabular}

(Source: Author generated).

Table 10. Regression of crude oil prices on Nifty 500.

\begin{tabular}{cccccc}
\hline Variable & Coefficient & Standard Error & t-Statistic & $\boldsymbol{R}$ Square & Probability \\
\hline Nifty 500 & 0.04697 & 0.0608 & 0.7722 & 0.0051 & 0.4415 \\
\hline
\end{tabular}

(Source: Author generated).

Table 11. Oil and Aviation companies (Correlation).

\begin{tabular}{ccccc}
\hline S. No. & Companies & Crude Oil & Exchange Rate & Nifty \\
\hline 1 & Jet Airways & 0.0007 & -0.1234 & 0.1361 \\
2 & National Thermal Power Corporation & -0.0680 & 0.0177 & -0.1138 \\
3 & Oil and Natural Gas Corporation & 0.0616 & -0.0630 & -0.0425 \\
4 & Powergrid Corporation & -0.0870 & -0.1033 & -0.0448 \\
5 & Indian Oil Corporation & 0.0229 & -0.0542 & 0.0301 \\
6 & GAIL (India) & 0.2105 & -0.0712 & -0.0166 \\
7 & Bharat Petroleum Corporation & -0.0459 & -0.0546 & -0.1336 \\
8 & Hindustan Petroleum Corporation & -0.0584 & -0.0240 & 0.0342 \\
9 & Petronet LNG & 0.0796 & -0.1839 & 0.1386 \\
10 & Indraprastha Gas & -0.1226 & -0.1505 & 0.1528 \\
\hline
\end{tabular}

${ }^{*}$ Significant at $5 \%$ level of significance. (Source: Author generated).

and visa-versa. On the other hand, we see that the stock return of Oil and Natural Gas Corporation Limited, GAIL (India) Limited, Petronet LNG Limited are positively and statistically significantly correlated to the crude oil return.

It is also evident that the stock returns of Jet Airways, Oil and Natural Gas Corporation, Powergrid Corporation, Indian Oil Corporation, GAIL (India) Limited, Bharat Petroleum Corporation, Petronet LNG and Indraprastha Gas are negatively correlated to the Exchange rate return. This indicates that as the return from exchange rate increases, there is a decrease in the stock price returns of all the companies and visa-versa. Hence, if rupee value depreciates the stock price return generated by all the companies would fall.

The correlation between the Nifty returns and the Stock returns of Jet Airways, Petronet LNG and Indraprastha Gas are positive and statistically signifi- 
cantly correlated. This means that an increase in the nifty returns causes an increase in the stock returns of the companies. The correlation between Nifty returns and stock returns of National Thermal Power Corporation and Bharat Petroleum Corporation is negative and statistically significant which means that a decrease in nifty return causes an increase in the stock returns.

Based on the results depicted in Table 12; we can infer that out of the ten selected companies from aviation and oil sector, only one company is exposed to rupee dollar exchange rate and only one company is exposed to change in crude oil price. Bharat Petroleum is significantly affected by the market movements out of all the selected companies. Crude oil price movements have a positive and significant impact on GAIL (India), while the impact is not significant for other companies. Broadly, we can conclude that the selected companies are not significantly impacted by crude oil prices directly.

In ADF (Table 13(a) \& Table 13(b)), it is essential to do the stationarity test.

Table 12. Regression analysis.

\begin{tabular}{|c|c|c|c|c|c|c|}
\hline $\begin{array}{l}\text { Sr. } \\
\text { No. }\end{array}$ & Companies & Variable & Coefficient & $\begin{array}{c}\text { Standard } \\
\text { Error }\end{array}$ & $t$-Statistic & Probability \\
\hline \multirow{4}{*}{1} & \multirow{4}{*}{ Jet Airways } & Crude Oil & -0.0082 & 0.1758 & -0.0469 & 0.9627 \\
\hline & & Exchange Rate & -0.4658 & 0.9440 & -0.4934 & 0.6226 \\
\hline & & Market & 0.2795 & 0.3497 & 0.7992 & 0.4258 \\
\hline & & $\mathrm{C}$ & 0.0194 & 0.0193 & 1.0032 & 0.3179 \\
\hline \multirow{4}{*}{2} & & Crude Oil & -0.0398 & 0.0694 & -0.5726 & 0.5681 \\
\hline & National Thermal & Exchange Rate & -0.2743 & 0.3729 & -0.7356 & 0.4635 \\
\hline & Power Corporation & Market & -0.1903 & 0.1382 & -1.3777 & 0.1710 \\
\hline & & $\mathrm{C}$ & 0.0067 & 0.0076 & 0.8838 & 0.3787 \\
\hline \multirow{4}{*}{3} & & Crude Oil & 0.0772 & 0.0921 & 0.8386 & 0.4035 \\
\hline & Oil and Natural Gas & Exchange Rate & -0.6762 & 0.4944 & -1.3677 & 0.1741 \\
\hline & Corporation & Market & -0.2341 & 0.1832 & -1.2783 & 0.2037 \\
\hline & & $\mathrm{C}$ & 0.0176 & 0.0101 & 1.7383 & 0.0848 \\
\hline \multirow{4}{*}{4} & \multirow{4}{*}{ Powergrid Corporation } & Crude Oil & -0.0434 & 0.0595 & -0.7288 & 0.4676 \\
\hline & & Exchange Rate & -0.5794 & 0.3196 & -1.8129 & 0.0725 \\
\hline & & Market & -0.1779 & 0.1184 & -1.5025 & 0.1357 \\
\hline & & $\mathrm{C}$ & 0.0129 & 0.0065 & 1.9808 & 0.0500 \\
\hline \multirow{4}{*}{5} & \multirow{4}{*}{ Indian Oil Corporation } & Crude Oil & 0.0849 & 0.3088 & 0.2751 & 0.7838 \\
\hline & & Exchange Rate & -0.8540 & 1.6583 & -0.5150 & 0.6075 \\
\hline & & Market & -0.0636 & 0.6143 & -0.1035 & 0.9178 \\
\hline & & C & 0.0472 & 0.0339 & 1.3932 & 0.1662 \\
\hline \multirow{5}{*}{6} & \multirow{5}{*}{ GAIL (India) } & Crude Oil & $0.1786^{\star}$ & 0.0719 & 2.4844 & 0.0144 \\
\hline & & Exchange Rate & -0.5554 & 0.3861 & -1.4386 & 0.1530 \\
\hline & & Market & -0.1723 & 0.1430 & -1.2043 & 0.2309 \\
\hline & & $\mathrm{C}$ & $0.0162^{*}$ & 0.0079 & 2.0513 & 0.0425 \\
\hline & & Crude Oil & -0.0193 & 0.0991 & -0.1946 & 0.8460 \\
\hline
\end{tabular}




\begin{tabular}{|c|c|c|c|c|c|c|}
\hline \multicolumn{7}{|c|}{ Continued } \\
\hline \multirow{3}{*}{7} & Bharat Petroleum & Exchange Rate & $-1.0712^{*}$ & 0.5324 & -2.0120 & 0.0466 \\
\hline & Corporation & Market & $-0.4740^{\star}$ & 0.1972 & -2.4037 & 0.0178 \\
\hline & & $\mathrm{C}$ & $0.0384^{\star}$ & 0.0109 & 3.5338 & 0.0006 \\
\hline \multirow{4}{*}{8} & & Crude Oil & -0.2697 & 0.4109 & -0.6563 & 0.5129 \\
\hline & Hindustan Petroleum & Exchange Rate & 0.0898 & 2.2065 & 0.0407 & 0.9676 \\
\hline & Corporation & Market & 0.2776 & 0.8174 & 0.3397 & 0.7347 \\
\hline & & $\mathrm{C}$ & 0.0756 & 0.0451 & 1.6773 & 0.0962 \\
\hline \multirow{4}{*}{9} & \multirow{4}{*}{ Petronet LNG } & Crude Oil & 0.1428 & 0.1572 & 0.9078 & 0.3659 \\
\hline & & Exchange Rate & -1.2143 & 0.8445 & -1.4380 & 0.1532 \\
\hline & & Market & 0.0529 & 0.3128 & 0.1692 & 0.8659 \\
\hline & & $\mathrm{C}$ & 0.0331 & 0.0173 & 1.9161 & 0.0578 \\
\hline \multirow{4}{*}{10} & \multirow{4}{*}{ Indraprastha Gas } & Crude Oil & -0.1162 & 0.0831 & -1.3990 & 0.1645 \\
\hline & & Exchange Rate & -0.2659 & 0.4461 & -0.5960 & 0.5523 \\
\hline & & Market & 0.1583 & 0.1653 & 0.9578 & 0.3402 \\
\hline & & $\mathrm{C}$ & $0.0331^{\star}$ & 0.0091 & 3.6292 & 0.0004 \\
\hline
\end{tabular}

${ }^{*}$ Significant at $5 \%$ level of significance (Source: Author generated).

Table 13. (a) Unit root test (Augmented Dickey Fuller) of Crude Oil; (b) Unit root test (Augmented Dickey Fuller) of Nifty 500.

(a)

\begin{tabular}{ccccc}
\hline Stationary Test & & & & \\
\hline Test & Score & $\boldsymbol{P}$-Value & C.V. & Stationary? \\
\hline ADF & & & & \\
\hline $\boldsymbol{P}$-value with No Constant & -9.3 & $0.1 \%$ & -2.0 & TRUE \\
Test stat with Constant Only & -9.3 & $0.1 \%$ & -3.0 & TRUE \\
Critical value with Constant and Trend & -9.2 & $0.0 \%$ & -1.6 & TRUE \\
$\boldsymbol{P}$-value with Constant, Trend and Trend squared & -9.2 & $0.0 \%$ & -1.6 & TRUE \\
\hline
\end{tabular}

${ }^{\star}$ Significant at $5 \%$ level of significance.

(b)

\begin{tabular}{ccccc}
\hline Stationary Test & & & & \\
\hline Test & Score & $\boldsymbol{P}$-Value & C.V. & Stationary? \\
\hline ADF & & & & \\
\hline $\boldsymbol{P}$-value with No Constant & -9.5 & $0.1 \%$ & -2.0 & TRUE \\
Test stat with Constant Only & -9.7 & $0.1 \%$ & -3.0 & TRUE \\
Critical value with Constant and Trend & -9.7 & $0.0 \%$ & -1.6 & TRUE \\
$\boldsymbol{P}$-value with Constant, Trend and Trend squared & -9.6 & $0.0 \%$ & -1.6 & TRUE \\
\hline
\end{tabular}

*Significant at 5\% level of significance (Source: Author generated).

The TRUE result implies that the same results which apply for independent data hold true if the data is stationary. The $P$-value less than $5 \%$ implies that the data is significant.

Also, when the critical value is less than the score we infer that the null hypo- 
thesis does not hold true and there is no unit-root present. ADF test indirectly, through the absence of unit root, signifies stability of the data present. Here, we conclude that crude oil prices as well as nifty do have a correlation and the data is stable (Table 14).

In co-integration, the $P$-value less than $5 \%$ implies that the data is significant. This implies that crude oil and Nifty 500 co-integrated and the data is significant and stable (Table 14).

In this case, the null hypothesis is rejected which implies that there exists a relationship between Crude Oil and Nifty 500.

\subsection{GARCH Model}

To investigate the volatility transmission, the Generalized Autoregressive Conditional Heteroscedasticity (GARCH $(1,1)$ ) test was conducted to understand the impact of oil prices on Sensex by taking Sensex as a dependent variable and crude prices have independent variable by using daily time series data covering the period between 2012 and 2017. GARCH model is an approach to estimate volatility in financial markets. The results of the tests for the GARCH $(1,1)$ test are presented as following (Figure 4, Table 15):

Table 14. Johansen's cointegration test.

\begin{tabular}{cccc}
\hline Cointegration (Johansen) Test & & & \\
\hline Test & Score & C.V. & Pass? \\
\hline Trace Test $(\mathrm{r}=\mathbf{0})$ & $\mathbf{0}$ & & $\mathrm{r}>\mathbf{0}$ \\
No Const & 42.4 & 12.3 & TRUE \\
Const-Only & 46.9 & 15.5 & TRUE \\
Const + Trend & 46.7 & 18.4 & TRUE \\
\hline
\end{tabular}

${ }^{*}$ Significant at $5 \%$ level of significance (Source: Author generated).

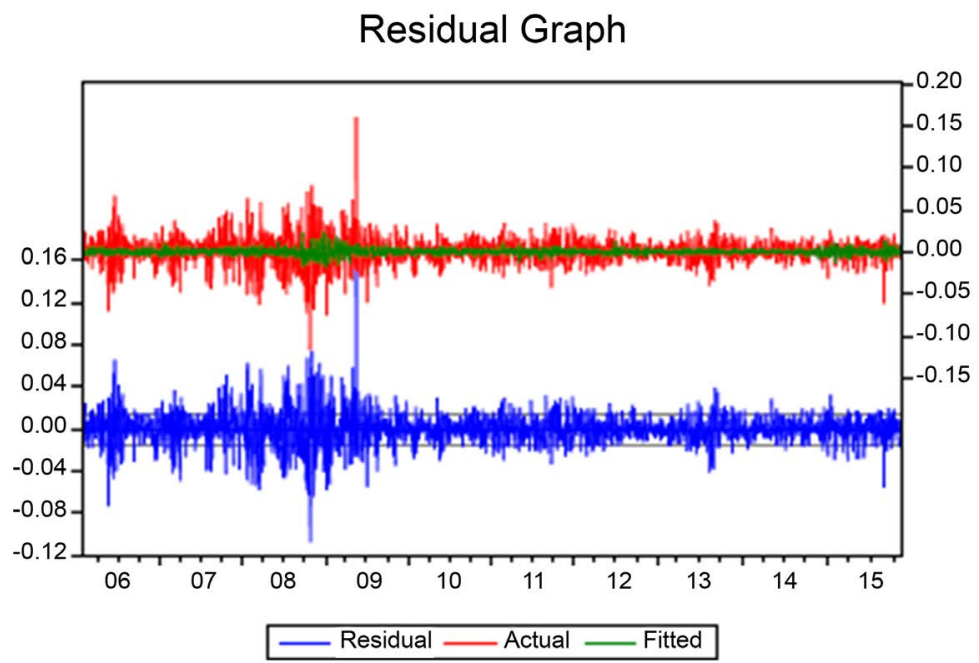

Figure 4. Residual graph for GARCH on impact on oil prices on Sensex (Source: Author generated). 
Table 15. Relation between crude oil prices and sensex.

\begin{tabular}{ccccc}
\hline SENSEX $(-1)$ & 0.050047 & 0.021099 & 2.372018 & 0.0177 \\
\hline Variance Equation & & & & \\
C & 0.00000266 & $4.86 \mathrm{E}-07$ & 5.473139 & 0.0000 \\
RESID $(-1)^{2}$ & 0.090125 & 0.007557 & 11.92541 & 0.0000 \\
GARCH $(-1)$ & 0.898554 & 0.008385 & 107.1577 & 0.0000 \\
Method: ML-ARCH (Marquardt)-Normal dis- & & & & \\
tribution & & & & \\
GARCH = C (4) + C (5) $\times$ RESID $(-1)^{2}+$ C (6) $\times$ & & & & \\
GARCH $(-1)$ & & & & \\
Variable & Coefficient & Std. Error & z-Statistic & Prob. \\
C & 0.000669 & 0.000212 & 3.156594 & 0.0016 \\
CRUDE & 0.103232 & 0.009654 & 10.69267 & 0.0000 \\
\hline
\end{tabular}

(Source: Author generated).

It can be seen from the above Table 15 that crude oil price shares a positive coefficient with Sensex indicating that there is a direct relationship between sensex and Crude oil. The $P$-value for crude oil is 0.0000 which is less than 0.05 . This indicates that the test is significant.

We can conclude that crude oil prices are significant in the volatility of the sensex. The independent variable was also significant influencing the volatility of dependent variable thus we can reject the null hypothesis. The null hypothesis rejection means that crude oil prices are significant to affect sensex and have the capacity to transmit shock on sensex.

\section{Conclusions}

The aim of this study is to analyse the influence of crude oil on stock market. Past studies about this topic have shown a significant relationship between crude oil and stock index though the degree of this relationship varies from market to market and time to time. The impact of crude oil on stock index is indirect via three factors: Interest rate, exchange rate and Inflation. In this research paper, we have explained each factor's relationship with crude and its combined effect on stock market. We have carried out correlation and regression analysis along with qualitative analysis of the following relationships.

1) Crude oil and Inflation -> Inflation and Nifty 500.

2) Crude oil and Exchange Rate -> Exchange Rate and Nifty 500.

3) Crude oil and interest rate -> Interest rate and Nifty 500.

According to this analysis, the correlation between Crude oil and inflation, interest rate and exchange rate is significant but weak. The correlation between these factors and Nifty 500 is also significant.

Coming to regression analysis, Crude oil (independent variable) influences Inflation, Interest rate and exchange rate only up to a small but significant extent. These factors (independent variables now) also influence Nifty 500 signifi- 
cantly.

The qualitative analysis suggests that the effect of these factors after getting influenced by Crude oil price change movements further affects certain sectors like FMCG, Banking, transportation, textile and agriculture that are included in Nifty 500 .

We have analysed the relationship between crude oil and stock index indirectly through correlation and regression analysis. We then tried to form a direct relationship between crude oil and Nifty 500 by using Johansen's Co-integration test.

Since Unit root test is the base requirement for Co-integration test, we conducted the Augmented-Dickey Fuller test. The unit root tests show that Nifty returns and crude oil prices are stationary at first level difference. This means that the statistical properties of the two factors remain constant over time. The Johansen's Co-integration test further proves that Crude oil prices and Nifty 500 returns are co-integrated i.e. long-term relationship between the time series is present and any of the time series can be used to predict other time series.

We investigated the transmission of volatility and shocks between crude oil price and Sensex. GARCH $(1,1)$ model results also supported the regression model that the crude price which is the independent variable is significant in the volatility of the Sensex returns which is the dependent variable.

\section{Conflicts of Interest}

The authors declare no conflicts of interest regarding the publication of this paper.

\section{References}

[1] Anderson, R.N. (1998) Oil Production in the 21st Century. Scientific American, 278, 86-91. https://doi.org/10.1038/scientificamerican0398-86

[2] Anderson, D.R., Sweeney, D.J. and Williams, T.A. (2008) Statistics for Business and Economics South Western. A Part of Cengage Learning, Third Indian Reprint, 553.

[3] Ader, S (2005) The Challenge of Higher Oil Prices, Asian Development Outlook, 66-76.

[4] He, S., Wang, S. and Lai, K.K. (2010) Global Economic Activity and Crude Oil Prices: A Co-Integration Analysis. Energy Economics, 32, 868-876. https://doi.org/10.1016/j.eneco.2009.12.005

[5] Aparna, A. (2013) Impact of Oil Prices on the Indian Economy. NMIMS Management Reviews, 23, 141-147.

[6] Shahid, C.S. (2010) Influence of the Risk Factors in Monetary Policy of Industrial Growth in India. Zenith International Journal, 8, 103.

[7] Bhattacharya, K. and Bhattacharyya, I. (2001) Impact of Increase in Oil Prices on Inflation and Output in India. Economic and Political Weekly, 36, 4735-4741.

[8] Ghosh, S. (2011) Examining Crude Oil Price-Exchange Rate Nexus for India during the Period of Extreme Oil Price Volatility. Applied Energy, 88, 1886-1889. https://doi.org/10.1016/j.apenergy.2010.10.043

[9] Basher, S.A., Haug, A.A. and Sadorsky, P. (2016) The Impact of Oil Shocks on Ex- 
change Rates: A Markov-Switching Approach. Energy Economics, 54, 11-23. https://doi.org/10.1016/j.eneco.2015.12.004

[10] Sadorsky, P. (1999) Oil Price Shocks and Stock Market Activity. Energy Economics, 21, 449-469. https://doi.org/10.1016/S0140-9883(99)00020-1

[11] Kang, W., Ratti, R.A. and Yoon, K.H. (2015) The Impact of Oil Price Shocks on the Stock Market Return and Volatility Relationship. Journal of International Financial Markets, Institutions and Money, 34, 41-54. https://doi.org/10.1016/j.intfin.2014.11.002

[12] Nandha, M. and Faff, R. (2008) Does Oil Move Equity Prices? A Global View. Energy Economics, 30, 986-997. https://doi.org/10.1016/j.eneco.2007.09.003

[13] Barsky, R.B. and Kilian, L. (2004) Oil and the Macro-Economy Since the 1970s, Journal of Economic Perspectives, 18, 115-134. https://doi.org/10.1257/0895330042632708

[14] Doya, K., Ishii, S., Pouget, A. and Rao, R.P. (2007) Bayesian Brain: Probabilistic Approaches to Neural Coding. MIT Press, Cambridge, MA.

[15] Berument, H.M., Ceylan, N.B. and Dogan, N. (2010) The Impact of Oil Price Shocks on the Economic Growth of Selected MENA Countries. The Energy Journal, 31, 149-176. https://doi.org/10.5547/ISSN0195-6574-EJ-Vol31-No1-7

[16] Engle, R. (1982) Autoregressive Conditional Heteroscedasticity with Estimates of the Variance of United Kingdom Inflation. Econometrica, 50, 987-1007. https://doi.org/10.2307/1912773

[17] Fatih, B. (2004) Analysis of the Impact of High Oil Prices on the Global Economy, International Energy Agency, 1-7.

[18] Blanchard, O.J. and Galí, J. (2007) The Macro-Economic Effects of Oil Price Shocks: Why Are the 2000s So Different from the 1970s? NBER Working Paper No. 13368, National Bureau of Economic Research. https://doi.org/10.3386/w13368

[19] Sarkar, A.N. (2008) Energy Security: Changing Dynamics and Emerging Future Energy Issues. Hydrocarbon Asia, 18, 47-52.

[20] Sarker, A.N. (2009) Global Strategic Oil Reserve-A Prognostic Scenario Analysis. Strategic Petroleum Reserve Report, 34, 20-34.

[21] Eastwood, R.K. (1992) Macroeconomic Impacts of Energy Shocks. Oxford Economic Papers, 44, 403-425. https://doi.org/10.1093/oxfordjournals.oep.a042055

[22] Gately, D. (1995) Strategies for OPEC's Pricing and Output Decisions. The Energy Journal, 16, 1-38. https://doi.org/10.5547/ISSN0195-6574-EJ-Vol16-No3-1 